\title{
EXU SEU SETE DA LIRA: DISPUTAS MIDIÁTICAS E INSTITUCIONAIS SOBRE O NORMAL, O ANORMAL E O PARANORMAL ${ }^{1}$
}

\author{
Dionisio Alves de Castro \\ Fábio Antonio da Costa \\ Jorge Luis Chaves de Assunção \\ Nathalie G. R. Quintarelli \\ Yuri Reis Schaider
}

\begin{abstract}
Resumo: A manifestação de uma entidade de umbanda, ao vivo, em dois programas de auditório, desencadeou em membros da plateia e em alguns telespectadores o estado de transe. A imprensa, a Igreja Católica e o Estado posicionaram-se publicamente e por meio de medidas institucionais a fim de que o fenômeno não ocorresse novamente. $\mathrm{O}$ caso da entidade Exu Seu Sete da Lira converteu-se em anedota, ocorrência extravagante cuja instância explanatória é disputada por discursos sociológicos, psiquiátricos e jurídicos. Nosso objetivo é descrever o caso e retomar uma discussão com os trabalhos científicos que sobre ele se debruçaram, a fim de demonstrar que o fenômeno deve ser explicado por si mesmo, pela sua presença e formas de presentificação, sendo os anteriores métodos explanatórios precários para a análise das relaçôes entre mídia, dom espiritual e instituiçôes estatais.
\end{abstract}

Palavras-chave: Dons espirituais; Mídia; Umbanda.

1 Escrito pelo Dionisio Alves de Castro (Estudante do Ensino Médio do Colégio Pedro II), Prof. Dr. Fábio Antonio da Costa (Departamento de filosofia do Colégio Pedro II), Jorge Luis Chaves de Assunção (Estudante do Ensino Médio do Colégio Pedro II), Nathalie G. R. Quintarelli (Estudante do Ensino Médio do Colégio Pedro II), Yuri Reis Schaider (Estudante do Ensino Médio do Colégio Pedro II). E-mail: philonatur@gmail.com. Esta pesquisa foi realizada com a colaboração dos meus alunos de Iniciação Científica do Colégio Pedro II, instituição federal situada no Rio de Janeiro, Brasil.

Debates do NER, Porto Alegre, Ano i 9, N. 35, P. 369-403, Jan./Jul. 20 i 9 


\begin{abstract}
A TV live broadcast of the manifestation of an entity of Umbanda on two talk shows unleashed a state of trance in some members of the studio audience, as well as in some spectators. The press, the Catholic Church and the State made public statements and took institutional measures to prevent the phenomenon from reoccurring. The case of the entity Exu Seu Sete da Lira became an anecdote, an extravagant occurrence whose sole explanation has been claimed by sociological, psychiatric and juridical discourses. Our goal is to provide a description of the case and reinstate a discussion with the scientific works that have engaged with it, in order to demonstrate that the phenomenon must be explained by itself, by its presence and forms of making-present, as previous explanatory methods have proven problematic for the analysis of the relations between media, spiritual gift and state institutions.
\end{abstract}

Keywords: Spiritual gifts; Midia; Umbanda.

\title{
ANEDOTAS: NEM GRACEJOS NEM ABERRAÇÓES. OU: DIFICULDADES DE ANALISAR O QUE NÃO SE CONVERTE EM OBJETO.
}

As anedotas não se reduzem a curtas narrativas, envoltas tanto pelo humor quanto pelo inusitado, cujo papel a desempenhar seria marginal em um contexto discursivo mais amplo. Não possuem elas em seu âmago, necessariamente, uma lição moral a ser extraída, tal como nas parábolas. Contudo, o mistério das anedotas pode estar exatamente em sua marginalidade, como um instrumento diretivo que, fora da narrativa mestra, para ela aponta, como que trazendo um iluminador caso exemplar. Não se nega a possibilidade de abrigar uma anedota em um discurso formal ou científico, na qualidade de caso. Sabemos, entretanto, desde o famigerado exemplo 
das abelhas descrito por Platão (2001, p. 23-24) no diálogo Mênon ${ }^{2}$ que a enumeração de casos não é capaz de perfazer uma definição ou atingir uma ideia: o caso não alcança o nível conceitual. Não é lícito supor, de imediato, que aquelas estratégias linguísticas desviantes do conceito ou tangenciadoras da narrativa mestra sejam simplórios volteios retóricos, passíveis de, até mesmo, resgatar maior rigor racional por meio de alguma paráfrase. Passado é o tempo em que a literatura científica deveria mais uma vez tecer longa justificativa a fim de não lançar a retórica no limbo do erro categorial ou do recurso puramente patológico ${ }^{3}$. Em seus trabalhos sobre as funçóes da metáfora ao longo da história do pensamento, Hans Blumenberg (2013) sinaliza que o problema não está em um inadequado uso da linguagem, mas sim em um conjunto de coisas incontornáveis, o qual resiste a assumir a condição de objeto:

Neste momento, surge a suspeita de que o conceito que não permite ordenar univocamente um complexo de experiências (como o permite o conceito de elefante, que contém o que se esperava ao nos registramos em uma agência de viagens para um safari) não passa de uma invenção, de uma ficção, de uma construção do intelecto humano. $\mathrm{O}$ conceito de liberdade não passaria de uma ilusáo etiquetada do homem, na falta de qualquer realidade correspondente, não exclusivamente um elemento derivado da natureza e de suas determinaçôes.

A questão, no entanto, é mais complicada. Os conceitos não só se baseiam nos objetos, mas também constituem objetos. O conceito é uma regra de representar as representaçóes de um certo modo, portanto uma representação

${ }^{2}$ Em sua discussão com o personagem Mênon sobre a definição de virtude, Sócrates compara o ato de enumerar as virtudes a um enxame de abelhas. Mesmo tendo esses insetos diferentes formas, todos eles compartilham de uma natureza em comum capaz de fazê-los partícipes de uma mesma espécie.

3 A título singelo de recordação, cabe mencionar as pesquisas de Max Black sobre o uso de metáforas na esfera científica, particularmente na obra Models and Metaphor: studies in language and philosophy; também ressaltamos o trabalho de Paul Ricoeur, Metáfora Viva, bem como as obras de Chaïm Perelman derivadas do seu projeto sobre a nova retórica.

Debates do NER, Porto Alegre, ano i9, N. 35, P. 369-403, JAN./JUl. 2019 

Jorge Luis Chaves de Assunção, Nathalie G. R. Quintarelli, Yuri Reis Schaider

da representação. Há assim conceitos que não se ligam a seus objetos senão como a própria regra que produz o objeto. ${ }^{4}$ (Blumenbereg, 2013, p. 81-82, grifos do autor)

Por certo que a chamada teoria da não conceitualidade, de Blumenberg, é debitada da distinção kantiana entre razão e entendimento, conceito e Ideia (Kant, 2000). Mais além, não se deve negar a grande dívida do autor em relação às observaçóes legadas por Kant, em sua Crítica da Faculdade do Juizo (1995), a propósito da metáfora como modo de figurar uma Ideia, ou seja, o meio disponível de tornar visível aquilo que é irrepresentável como objeto. Para as observações que se seguirão ao longo deste texto, o mais relevante nos trabalhos de Blumenberg $(2010 ; 2013 ; 2015)$ está na situação inelutável das metáforas e anedotas, visto que, para ele, é incontornável que o ser humano reflita sobre totalidades inconvertíveis em conjunto de objetos empíricos: muitas dessas totalidades não podem ser pensadas como conjuntos maximamente extensos, porquanto carregam consigo também a marca do incondicionado. Se nos voltarmos para as análises que esse autor realizou sobre uma anedota - precisamente aquela que descreve a risada da serva trácia ao ver Tales de Mileto cair em um fosso -, notaremos que os variados modos como a historieta foi posta ao longo da história da filosofia desempenhava a função de indicar a determinação do lugar da atividade teórica, não somente em relação às atividades práticas, mas também como modo de conduta em relação à vida cotidiana ${ }^{5}$ (Blumenberg, 2015). Mesmo as alterações, inclusóes e exclusôes promovidas na anedota, aparentes erros de tradução, calhavam bem para desempenhar a função de caso exemplar capaz de iluminar um discurso. Essa luz lançada não precisa ser entendida

4 Dois temas utilizados, nesta parte do texto, para exemplificar a não conceitualidade são liberdade e inconsciente.

5 Para uma discussão sobre a determinação do lugar da atividade teórica na Antiguidade, conferir. JAEGGER, Werner. On the Origin and Cycle of the Philosophic Ideal of Life. In: JAEGGER, Werner. Aristotle: fundamentals of the history of his development. Tradução de Richard Robinson. Oxford: Clarendon Press, 1968. 
estritamente como um fragmento discursivo para a interpretação do resto de uma exposição, porque ela ultrapassa o texto ao também ser um meio de gerar específica disposição de humor no leitor, simultaneamente apontando para um modo de se conduzir na vida. Assim como as placas estão à margem da estrada, metáforas e anedotas podem estar à margem do discurso principal: em ambas, prevalece a função indicativa de orientação.

A anedota sobre a qual nos debruçaremos, aqui nomeada como o caso do Exu Seu Sete da Lira, não dispóe do mesmo status daquela sobre a serva trácia, suposta como protoimagem do filósofo. Na seara do anedotário, há aqueles causos que não são preparados por uma exposição prévia, nem deles se segue uma explicação ou análise. Há das anedotas sub-reptícias, autenticamente marginais, porque emergem e imergem no discurso sem prestar contas de si mesma. É como se a teoria se deparasse com uma experiência bruta, pré-temática; como se a narrativa deixasse escapar, ou fizesse questáo de apontar, ainda que involuntariamente, para a pedra no meio do seu caminho.

Ao redigir o livro O Negro Brasileiro, Arthur Ramos (1940) emprega, em seu capítulo sobre o fenômeno da possessáo, um caso recolhido por Osório Cesar. Narra-se a possessão de Joaquim Carioca, suas contorçôes e agonias, a modificaçáo dos tons de voz e pele. Contudo, longe de ser mais uma recorrente descrição do transe, existe uma observação de um modo todo peculiar. Quando a entidade Oniara possuía Joaquim Carioca, esse passava a falar perfeitamente em língua geral ou tupi. Pelo que havia sido averiguado, o possesso jamais teve contato com essa linguagem. Todo o edifício teórico, com profundas raízes psicanalíticas, soerguido pelo autor nos capítulos anteriores, em nenhum momento foi capaz de oferecer uma explicação para essa xenoglossia. Por mais que se revirem e desvirem as observaçóes sobre transferência, atavismo, recalque, mimetismo, nenhum desses conceitos foi capaz de valer o autor para a explicação do ocorrido. Fica a anedota de Joaquim Carioca como uma pedra bruta, insubmissa ao esmeril teórico? Somente é possível ultrapassá-la porque o corpo do texto está contra ela imunizado. $\mathrm{O}$ quadro discursivo carregado em tintas 
psicopatológicas e desqualificadores morais borra a singularidade do evento, transportando o mesmo na aluvião dos transtornos ${ }^{6}$.

A estratégia de emprego da anedota por Roger Bastide é de todo díspar em relação ao que foi descrito anteriormente. Na obra $O$ candomblé da Bahia (Bastide, 1961), em um capítulo sobre o transe, após tecer consideraçōes históricas e teóricas sobre a forma de análise do fenômeno, o autor pede licença para introduzir dois causos. O primeiro, referente a um jovem filho de Xangô que, por mais esforços envidados, por mais escrupuloso que fosse em seguir os ritos, náo conseguiu entrar em transe. O segundo, em que é exposta a participação de um delegado, de classe média, de costumes recatados e discretos, muito cioso do seu comportamento civilizado. É o caso que o delegado incorpora Yemonja, dando vazáo aos comportamentos arquetípicos da divindade, o que inclui o ato de pedir dinheiro aos participantes da roda de candomblé. Ao sair do transe, o delegado se envergonha das açóes executadas inconscientemente. Ambos os casos estão postos com marcadores relevantes (Bastide, 1961, p. 251-252). Mimetismo ou atavismo não são indicadores suficientes para descrever a possessão; da mesma maneira, o primitivismo, a precariedade cultural, a suposta carência de civilidade nấo são marcas daqueles mais predispostos à incorporaçáo. Como, na obra referida, Roger Bastide tem mais interesse em oferecer a estrutura geral do que seria o candomblé, os dois casos se esvaem ao longo da narrativa, simplesmente apontando para a sua possibilidade de implodir o contexto acadêmico externo à obra, exatamente aquele que faz uso das categorias em que os casos citados náo se enquadram. Sublinhar os descompassos entre categorias recorrentes e os casos mencionados é crucial para a compreensão da constituição da anedota capital deste estudo: o caso do exu Seu Sete da Lira. Como veremos, náo se trata de meramente

${ }^{6}$ Não é irrelevante mencionar que o caso citado por Osório está em um texto intitulado Contribuiçöes ao estudo do espiritismo como fator predisponente de perturbaçôes mentais. Como veremos mais adiante, o emprego de categorias acusatórias, qualificadores morais e descriçóes exóticas descontextualizadas possuem clara funçáo de apropriaçáo do evento por parte de instituiçôes: nâo se trata de prática simplesmente arbitrada pelo indivíduo.

Debates do NER, Porto Alegre, ano i9, N. 35, P. 369-403, Jan./Jul. 20 i 9 
sinalizar para um erro de análise, mas sim demarcar a recorrências de algumas estruturas que apagam eventos.

Com ares de anedota picaresca, eivada de rocambolescas reviravoltas, assim a obra Chacrinha, a biografia (Monteiro; Nassif, 2014), trata do caso do Exu Seu Sete da Lira, em capítulo particularmente dedicado ao assunto. Em 29 de agosto de 1971, por volta das dezenove horas, mãe Cacilda de Assis $^{7}$, reconhecida como sacerdotisa de umbanda e compositora musical, adentra ao vivo no programa de auditório Buzina do Chacrinha, televisionado pela emissora Globo. A médium chega perante o público já possuída pela entidade Exu Seu Sete da Lira ${ }^{8}$, trajando capa, cartola, portando uma garrafa de cachaça e charuto; seguida por homens e mulheres que reproduziriam no palco algumas práticas religiosas típicas do seu terreiro, então localizado em Santíssimo. Durante a sessão de umbanda transmitida em tempo real, dançarinas do programa de auditório caíram em transe, assim como pessoas da plateia. Todos aqueles acometidos pela alteração da consciência eram imediatamente socorridos pelos auxiliares de mãe Cacilda. Quarenta minutos após a apresentação na TV Globo, mãe Cacilda de Assis aparece no programa Flávio Cavalcanti, transmitido pela TV Tupi. Mais uma vez, transcorrem transes entre aqueles que compunham a plateia do programa, igualmente televisionado ao vivo.

7 O objeto de estudo desta pesquisa é o fenômeno da presença de Seu Sete da Lira em programas de televisão ao vivo, bem como a repercussão dessa aparição nas mídias escritas, precisamente durante o período de 1971. Elementos biográficos da médium Mãe Cacilda de Assis podem ser conferidos na biografia de Chacrinha, já mencionada, assim como na obra de Muniz Sodré e Raquel Paiva (2002)

8 Cabe ressaltar que, neste caso, trata-se de um tipo de entidade conhecido como exu catiço, que não se pode confundir com exu entendido como Orixá. Para uma análise da diferenciação entre exu catiço e exu orixá, ver Capone (2004). Para uma análise das caraterísticas próprias dos exus de umbanda, também levando em conta suas hierarquias, conferir Ortiz (1999). 
O principal objetivo deste estudo é demonstrar como o evento do Seu Sete sofreu um processo de desacontecimento, de despresentificaçâa ${ }^{9}$, ao fim se convertendo em anedota, caso curioso que margeia narrativas principais; evento neutralizado, mas com potencial disruptivo. Os discursos que apagam o evento, veiculados pela mídia escrita, não podem ser pensados como apartados de práticas. A partir da aparição de Seu Sete em duas emissoras renomadas, pressóes provenientes tanto da mídia quanto do Ministério das Comunicações, então encabeçado por Hygino Caetano Corsetti, resultaram em um acordo de autocensura: uma medida institucional que também promoveu a obrigação de previamente gravar os programas de auditório e enviá-los à análise da censura. A exposição das categorias acusatórias empregadas pela imprensa revelará a recorrência de um padrão, este capaz de demonstrar que tais discursos são, simultaneamente, índices de si mesmos

9 A ideia de desacontencimento ou despresentificação são inspiradas nos trabalhos de Hans Gumbrecht, particularmente pela obra Produção de presença: o que o sentido não consegue transmitir (2010). Como ficará claro ao longo do texto, a condição anedótica do evento em análise possui um duplo aspecto: é elemento marginal em uma narrativa mestra; é uma anedota/caso que carece de ser interpretada por uma instância teórica. Nessa medida, tudo o que ali ocorreu é fruto de um sentido externo ao evento em si, ou seja, ele não instaura por si mesmo sentido, mas seu sentido subjaz a uma instância que se reclama como fonte de sua interpretaçấo. A retomada da presentificação desse evento passa por dois rumos. Em primeiro lugar, a anedota pode ser a verdadeira chave de iluminação da narrativa mestra, na medida em que aquela resguarda uma série de acontecimentos obnubilados por esta. Quando a narrativa mestra tem caráter teorético, a instância externa responsável por conferir o sentido da anedota pode ser destruída pelo evento das seguintes formas: os conceitos teóricos não dão conta do fenômeno em si, assim como as produçóes ou desdobramentos do fenômeno náo são abarcados pelos conceitos; verifica-se a precariedade conceitual para a análise do fenômeno, seja pela disputa ou bricolagem entre instâncias teóricas para a determinaçáo do objeto, seja pelo uso de termos pseudoteóricos ou próprios da ordem da vida cotidiana, como os discursos moralistas e as prescriçóes para controle social. Em segundo lugar, descrever os efeitos de presença produzidos pelo evento, os desdobramentos do seu acontecimento, bem como a discussão sobre os meios de sua materialização, estas são formas de regatar sua presentificação.

Debates do NER, Porto Alegre, ano i9, N. 35, P. 369-403, Jan./Jul. 2019 
e dispositivos. Para que essa hipótese teórica não se afigure de imediato como excessivamente vaga, vale ressaltar que o discurso da imprensa, ao empregar categorias de acusação como primitivismo, imoralidade, falta de cultura, acaba por revelar que a sua própria estrutura é constituída pela precariedade: ao apontar para o grotesco, ela se revela grotesca. Ao expressar sua incapacidade reflexiva de lidar com o fenômeno para além da acusação e da tentativa de imunizá-lo, de torná-lo ineficaz, a voz da cultura mediana, representada pela imprensa, marca a sua abissal diferença em relação a outros povos, considerados como muito cultos. Estes foram capazes de tomar o evento como objeto teórico. Em última instância, o que observaremos durante a análise do evento em discussão é, em primeiro lugar, o modo de tratamento dado pela imprensa, lançando mão de uma linguagem pseudoteórica, eivada de moralismo e patologização. Em segundo lugar, por oposição, a tematização da relação entre possessão/transe e mídia, em solo estrangeiro, acarretou investigaçóes sobre empresas e aglomerados empresariais como os verdadeiros agentes da possessão; a possibilidade de transmissão de dons espirituais à distância, através de mídias. Ao fim e ao cabo, a verdadeira condição fantasmagórica não recai sobre a entidade espiritual, mas sim sobre o discurso desprovido da vida do conceito e das carnes da realidade. Sua condição espectral, sem autor, pairando em todos os cantos pela uniformidade discursiva, desempenha o contínuo papel de dispositivo capaz de acionar um fantasma moderno: a polícia moral.

\section{O PERIGO DA IMAGEM: FRACASSO DO TERMO CRENÇA E AS DISPUTAS PELO PODER DE INTERPRETAR}

Restringimos as nossas investigaçóes ao ano de 1971, com o recorte geográfico restrito aos periódicos publicados no Rio de Janeiro. Para além dos registros do ano referido em que constam as atividades de Cacilda de Assis como compositora de músicas populares, particularmente de marchinhas de carnaval, a primeira informação que explicita as atividades da médium 
com a entidade Seu Sete, em âmbito televisivo, aparece na coluna de Zózimo Barroso do Amaral. Na edição do dia 2-3 de maio de 1971, em tom jocoso, o colunista indica alaridos sobre a fama dessa entidade, sua familiaridade com personalidades da televisão, em especial com Chacrinha. Zózimo reforça tal proximidade ao declarar:

Aliás, os corredores das Tvs transbordam de passes e transes paramísticos, numa atividade febril de ocultismo. Nossa versão do meio mais importante da aldeia global, ao que parece, interpretou o tribalismo ao pé da letra, e daqui a pouco certos setores da TV serão sucursais do Haiti (Amaral, 1971, p. 3)

Enquanto a televisão afigura-se na nota como signo do progresso, as referências ao tribalismo e ao Haiti pesam sobre o termo aldeia, na expressão "aldeia global". O tom chistoso do comentário ganha ares mais cordiais em outra matéria sobre a entidade, agora estampada na revista $O$ Cruzeiro, ainda no mesmo mês. Não é a primeira vez que tal revista está associada a uma querela que envolve mídia e religióes de matriz africana. A literatura acadêmica já conta com registro de fôlego que reconstrói os esforços da revista O Cruzeiro por suplantar a publicação francesa Paris Match, trazendo à luz fotos da iniciação de yawos em maior número e exotismo do que aquelas tornadas públicas na França pelas lentes de Henri-Georges Clouzot (Tacca, 2009). Nada perdemos ao gastarmos breves momentos ressaltando alguns aspectos dessa polêmica reportagem brasileira, intitulada As noivas dos Deuses Sanguinários (Silva; Medeiros, 1951). Se já o título depara-nos com o sensacionalismo, a linguagem que molda a narrativa da reportagem, responsável pela atribuição de sentido às fotos encartadas, flutua entre a descrição das ocorrências e as adjetivaçóes patológicas e primitivistas. Há um jogo entre proximidade e distância, ao enunciar a ocorrência das fotos na cidade de Salvador, mas igualmente ao marcar o início da narrativa pela obscuridade da noite, o calor, os aromas e ares de mistério. Como se acompanhasse um thriller, o leitor é instigado pelo caráter estranho de uma ocorrência em ambiente que lhe é familiar. A descrição por termos patológicos permite 
uma assepsia do lugar do leitor, na medida em que ele não está acometido pelo transtorno psíquico daqueles retratados. Afasta, porque o leitor não seria como os bárbaros fotografados; aproxima, porque são esses homens e mulheres presentes no seu cotidiano. Em termos gerais, a narrativa consegue imunizar o seu leitor: introduz o corpo estranho e assegura os meios para que ele não seja contaminado. A cápsula que envolve o corpo estranho é exatamente a linguagem familiar, em seu duplo sentido: familiar porque é própria da cotidianidade; familiar porque não tece análise alguma, apenas adjetiva no interior do espectro da anormalidade e da moralidade.

Em treze de setembro de 1951, Roger Bastide envia carta ao seu amigo Pierre Verger - linhas estas que confessam a vanidade de suas críticas endereçadas à reportagem de Paris Match e aos trabalhos de Clouzot sobre Candomblé. Neste momento, Bastide já está ciente das fotos de José Medeiros e da famigerada reportagem sobre a iniciação, ainda que a publicação da revista date de quinze de setembro de 1951. Dois momentos da carta merecem destaque. Em primeiro lugar, o confidente de Verger supóe que o resultado de suas críticas públicas ${ }^{10}$ a Clouzot seriam temíveis: "Tudo isso vai terminar sem dúvidas por campanhas de imprensa, batidas policiais, e não sei mais o quê: pelo menos tenho medo disso." (Bastide; Verger, 2017, p. 212, grifos nossos). A imprensa e a polícia aqui já se afiguram como os fatores perigosos, cuja irrupção poderia desencadear reações persecutórias incontroláveis. Em segundo lugar, a forma de controle narrativo a qual as fotos deveriam estar submetidas a fim de não sofrer ataques por parte dos terríveis agentes mencionados:

Somente, o drama, é que as fotos de Medeiros, como as de Clouzot, não ilustram artigos científicos, e que sua publicação pode atrapalhar o trabalho etnográfico que você está fazendo. No entanto, você precisa agora escrever um livro sobre a iniciação, com a descrição total e completa das cerimônias, como você fez com tanto sucesso para o "dar de comer à cabeça". Enquanto isso,

${ }^{10}$ Particularmente contra Clouzot, Bastide redigirá dois trabalhos na revista Anhembi, cujos títulos são A etnologia e o sensacionalismo ignorante e $O$ caso Clouzot e Le Cheval de Dieux.

Debates do NER, Porto Alegre, Ano i 9, N. 35, P. 369-403, Jan./Jul. 20 i 9 
provavelmente vou ainda escrever uma nota sobre a reportagem de Medeiros, mas insistindo sobre a crise moral dos candomblés, e o fato socioeconômico que provocou a crise. (Bastide; Verger, 2017, p. 212-213)

Nem críticas, nem desqualificaçóes, muito menos a pecha da barbárie. Nada disso será encontrado na matéria de O Cruzeiro, datada de dezenove de maio de 1971. Intitulada Salve Seo Sete: a nova dimensáo da umbanda (Lopes; Queiroz; Wanderley, 1971) a matéria de Wanderley Lopes, com fotos de Vieira de Queiroz e Indalécio Wanderley, traz a imagem completamente amistosa e familiares de um exu incorporado. Destaca-se a ausência de fins lucrativos nas consultas dadas pela entidade, assim como reforça-se o entorno de pessoas qualificadas que depositam sua fé nas manifestaçôes de mãe Cacilda. Com o título de O Maracanã da Fé (Lemos; Queiroz; Vieira, 1971), a revista retoma a figura de Seu Sete, agora oferecendo detalhes sobre frequentadores e ocorrências no terreiro de Santíssimo. Artistas como Emiliano de Queiroz, Neusa Amaral, Selma Lopes, Guerra Peixe, Sérgio Bitencourt, Lúcio Mauro, Chacrinha e uma plêiade de esportistas e membros das forças armadas são apresentados como adeptos da mesa de Seu Sete. Mantendo a narrativa de credibilidade, a revista colhe e publica depoimentos de curas alcançadas pelos participantes, estes devidamente qualificados com sua idade e profissão. Tal discriminação serve como testemunha de que as sessões não eram compostas por uma choldra carente das luzes culturais. $\mathrm{O}$ que há de mais relevante nessa última reportagem são dois depoimentos de Seu Sete que parecem vaticínios sobre as ocorrências que se desdobrariam poucos meses depois. Ainda que seja considerada como obra de assistência popular e frequentada por políticos, o exu pondera:

Meu filho, a umbanda só faz caridade. Exus, Pretos-Velhos, Caboclos, Crianças - todo o povo da direita e da esquerda astral - fazem o bem sem olhar a quem. Umbanda não se mete com política, nem com as coisas do governo. A umbanda só trata do amor universal. Cura o corpo para curar o espírito. É por isso que nós estamos crescendo. ( Lemos; Queiroz; Vieira, 1971, p. 43) 
Esta primeira declaração parece não suspeitar de que o governo se sentiria incomodado com as práticas do terreiro de Santíssimo. Poucas linhas adiante, a entidade parece prever por quais meios esse incômodo eclodiria: "- Se Cristo vivesse hoje - vai dizendo o Rei da Lira - ele pregaria seu Evangelho através de uma cadeia de televisão. Pelo satélite. O amor chegaria mais rápido ao coração do rebanho."(Lemos; Queiroz; Vieira, 1971, p. 43, grifos nossos).

Se a imitação de Cristo deve seguir o seu fado completo, Sete da Lira verá o momento da pregação via satélite desencadear o capítulo da crucificação pela imprensa, pelo governo e pela Igreja Católica.

Antes de analisarmos as consequências da aparição de Seu Sete, parecenos necessário perguntar pela natureza da imagem nas religióes de matriz africana. Os registros sobre a proibição de fotografias, imagens de entidades incorporadas ou de cerimônias são múltiplas e antigas, mesmo que esse costume tenha se afrouxado ao longo dos anos. Possíveis perseguiçóes ou discriminaçóes dos possessos; a importância do segredo e da ocultaçáo dos fundamentos cerimoniais, geralmente são os fatores mais apontados como justificativa para a proibiçãao ${ }^{11}$. Todavia, permanece a questão: a imagem é só um veículo no qual adere um sentido, do qual um sentido pode ser extraído; ou a imagem é uma coisa, algo que contenha propriedades e virtudes, uma coisa capaz de desencadear reaçóes que não passam pelo campo do sentido comunicado a outro?

A guisa de prefácio, em abril de 1943, com o título de Ao Leitor, Lydia Cabrera oferece uma introdução à sua obra $A$ Mata em que o tema das imagens proibidas recebe sua justificação, bem como a natureza da maleabilidade de tal proibição:

As ngangas, os orixás "montados", as pedras em que são adorados, as cerimônias não devem ser fotografadas em hipótese alguma. Nesse ponto e até esta data, santeros e paleros são inflexíveis. Já me havia esquecido da peremptória negativa de Baró ao solicitar-lhe, havia três ou quatro anos, que me permitisse

${ }^{11}$ Para uma discussão sobre os usos das fotografias e filmagens no candomblé, conferir. Castillo (2013) e Port (2006). 
retratar sua nganga, quando chegou um dia de improviso, trazendo nada menos do que o sacro-mágico e terrível caldeirão, escondido dentro de um saco negro. O espírito que nele montava havia manifestado a Baró que queria ser fotografado e concordava que a moana mundele ficasse com o retrato. $\mathrm{O}$ velho apressava-se em cumprir aquele capricho inesperado de sua nganga e, tranquilo, autorizava-me - "com licença da prenda" a publicar a fotografia, se tal fosse meu desejo.

É a única nganga que se fotografou em Cuba. Também, pela primeira vez na vida, Baró consentiu em permanecer imóvel durante alguns segundos diante da lente, o mensu inquietante de uma câmera.

Ele me havia negado este favor, não por desconfiança de minhas boas intenções, mas por recear que sua imagem fosse parar por acaso nas mãos de outro bruxo, o qual, dono do retrato, poderia enfeitiçá-lo e acabar facilmente com ele na ponta de alfinetes ou no lukambo finda ntoto (em um túmulo). Quanto a sua nganga, profanação à parte, a poderiam amarrar e debilitar. (Cabrera, 2012, p. 21, grifos do autor)

A questão da proibição de fotografar parece ter alguma relação com a possibilidade do seu uso mágico, particularmente vinculada como a condição daquele que está de posse do material. De início, a fotografia não parece dispor de princípio ou virtude ativa alguma, a não ser quando adequadamente manipulada. Ora, mas o que se dá com a foto parece ser o mesmo que se dá com diferentes materiais empregados nas cerimônias: para que disponha de caráter veicular e vinculante, para que o material se converta em médium de variegadas ações, faz-se necessário transmutá-lo da condição profana para o estado de sacralidade. Aparentemente, este é um ponto trivial, já que é notória a distinção entre objetos sagrados e profanos (Eliade, 1992). Todavia, um clássico problema teológico/religioso mais uma vez se apresenta, aquele da relação entre material, sacralização e crença dos indivíduos envolvidos: a natureza da conjunção desses fatores foi longamente discutida no Ocidente, particularmente a partir das querelas sobre a presença real do corpo e do sangue de Cristo na eucaristia (Pelikan, 2015). Em geral, a suposição prévia é de que o estado subjetivo da crença seja o fator principal 
de nexo entre material, sagrado e indivíduo. Mas, talvez, seja possível centrar o polo mais forte na própria sacralização, considerando o elemento da crença como desnecessário. Quando George Dumèzil, em Ideias Romanas (1969), traça a distinção entre fé e credo - ao mesmo tempo explicitando que o termo fé, aos romanos, mais se afigura como um acordo comercial ou um pacto jurídico, em que a relação é de fidelidade instaurada no dar e receber -, a crença como disposiçáo subjetiva sobre a verdade da existência da entidade não aparece. Certamente, toma-se como pressuposto de que a crença seja a condição de possibilidade para o pacto ou acordo, mas tal não é necessário. $\mathrm{O}$ pactuante pode realizar um acordo sem crença na entidade, mas apostando em uma eficácia, o que equivale, em linguagem cotidiana, a um pagar para ver. Sob outro aspecto, nem a expectativa da eficácia se faz necessária, porque a convocação ao pacto pode partir da própria entidade, náo do indivíduo, por vezes adquirindo o caráter de um pacto por captura. Eis o risco da presença, que imensamente resiste a ser capturado por fotografia e filmagens, tão bem ilustrado por uma anedota de Yvonne Maggie:

Às vezes sentia-me como num teatro, vendo um espetáculo dramático, catártico, agressivo, pois vez por outra os médiuns possuídos diziam palavróes. Mas ao mesmo tempo tinha a impressão de que não eram homens que via e sim deuses na terra, tão marcadas eram as expressóes corporais dos atores. Minha confusão aumentou quando vi um aluno meu, que assistia à cerimônia, "cair no santo». Era um transe desordenado e os médiuns, imediatamente, ajudaram-no. Seria a primeira vez que isso lhe acontecia? Tive medo, mas ao mesmo tempo tal fato incentivou-me a prosseguir com a pesquisa. Se essa experiência cultural, à qual assistia como observadora, era uma escolha entre as limitadas opçóes culturais, talvez eu, como qualquer um daqueles médiuns, pudesse entrar em transe e ser um cavalo dos deuses. Depois dessa primeira impressão pude reconstituir os fatos. (Maggie, 2001, p. 48)

O depoimento de Maggie corrobora nossas observaçóes sobre a crença. Ainda que a umbanda ou o terreiro sejam objetos de arbítrio para uma pesquisa, como opçóes de estruturas culturais de análise, o medo de ser 
presa da possessão indica um pacto a despeito do seu arbítrio e de suas crenças. A presença da investigadora reconhece a presença do inaudito, da possibilidade de ser capturado por ele.

\section{PERDA DE ORIENTAÇÃO: FENÔMENO PERIGOSO POR RESISTIR A ENQUADRAMENTOS}

Em uma sexta-feira, três de setembro do ano em discussão, o Jornal do Brasil anuncia as consequências das apariçóes do Seu Sete. Dedicando praticamente uma folha inteira ao caso, a matéria estampa o título Tvs firmam protocolo contra show de baixo nivel. Walter Clarck, representando a TV Globo, e José da Almeida Castro, em nome da TV TUPI, reúnemse na sede desta última emissora no dia anterior à publicaçấo da matéria jornalística, com a finalidade de assinar um acordo que salvaguardaria a livre iniciativa da televisão brasileira, bem como zelaria pelo nível elevado da cultura popular. Destacaremos apenas duas cláusulas que bem representam a linguagem e a natureza do acordo:

$1^{\circ}$ Fica expressamente proibido:

a. apresentar, em qualquer programa e sob qualquer pretexto, pessoas portadoras de deformaçóes físicas, mentais ou morais;

b. apresentar quadros, fatos ou pessoas que sirvam para explorar a crendice ou criticar ou incitar a superstição, bem como falsos médicos, curandeiros, ou qualquer tipo de charlatanismo. (Jornal do Brasil; 03/09/1971, p. 12)

Ainda na mesma página, em quadro intitulado Dom Eugênio condena exibição mediúnica, o jornal relata a reunião ordinária encabeçada por Dom Eugênio Salles e Dom Ivo Lorscheiter, da qual resulta uma posição pública sobre a aparição televisiva de Seu Sete. A posiçâa da Igreja Católica é assim introduzida pelo jornal: 
Ao examinarem a exibição mediúnica do domingo, os bispos do Rio de Janeiro concluíram que "já não se trata mais de uma questão religiosa, mas de saúde pública: os acontecimentos exigem profunda reflexão por parte dos responsáveis pelos meios de comunicação: a imagem do Brasil no exterior ficou prejudicada com a exibição de uma subcultura Quatro conclusôes são extraídas a partir das reflexóes dos bispos e demais participantes da reunião, sendo elas:

i. Os fatos ocorridos domingo na TV Tupi e TV Globo vão exigir dos seus responsáveis profunda reflexão. Desencadearam um processo irreversível que movimentou toda a população, invadiu as residências e nelas projetou a subcultura.

ii. O problema já sai da área religiosa e ganha um agravante ao atingir o aspecto relacionado com a saúde pública, o que vai exigir providências imediatas dos órgãos responsáveis. Através de programas como Eu Juro que $\mathrm{Vi}$ as televisóes estão promovendo charlatôes e levando os mais ingênuos a deixarem para segundo plano as curas da ciência.

iii. Sem entrar no mérito da liberdade de crença e de fé individual, mas chegando-se ao bom-senso, conclui-se que esses programas tornaram negativa a imagem do Brasil, inclusive no exterior. Não é justo que os meios de comunicação de que dispomos levantem a bandeira do subdesenvolvimento. O episcopado acha que a hora é de reflexão.

iv. Levar-se uma coletividade a uma atitude de histeria é por si só perigoso. Uma pessoa em transe torna-se incontrolável e um conjunto de pessoas, mais ainda (Jornal do Brasil, 1971, p. 12).

O pronunciamento da Igreja Católica sintetiza as categorias básicas em que o fenômeno será enquadrado nas mídias escritas: o charlatanismo, a subcultura e a doença mental. Deve-se notar a ruptura com a familiaridade, a qual era perceptível em reportagens anteriores veiculadas pela revista $O$ Cruzeiro. Um marcador de ruptura é o emprego da expressão "[...] invadiu as residências". No outono de 1919, Sigmund Freud publica um texto chamado Das Umheimlich, termo difícil de traduzir, podendo ser assumido como 
significando assombroso, assustador, inaudito, ominoso. Em sua estrutura etimológica, também analisada por Freud em tal texto, a palavra resguarda o sentido de não familiar, aquilo que escapa à familiaridade, ao costumeiro. Não nos interessa aqui as formulações psicanalíticas que Freud emprega para analisar o fenômeno do inaudito, mas nos é de grande interesse a estrutura básica a partir da qual o autor discutirá o fenômeno da estranheza:

Em geral, Jentsch não foi mais além deste nexo do ominoso com o novo. Encontra a condição essencial para a ocorrência do sentimento na incerteza intelectual. O ominoso seria sempre, em verdade, algo dentro do qual alguém não se orienta, por assim dizer. Enquanto um homem melhor se oriente dentro do seu meio, mas dificilmente recebera das coisas ou acontecimento que haja nele a impressão do ominoso. (Freud, 1992, p. 221)

Freud assume essa descrição inicial do fenômeno como o campo a partir do qual discutirá o tema com o interlocutor Jentsch. Não é a perda de orientação aquilo que o pai da psicanálise descartará, mas a falta de agudeza para perceber o que etimologicamente, ao menos na língua alemá, está diretamente associada à familiaridade. A ambiguidade é constitutiva tanto da palavra quando do objeto por ela nomeado, assim como a perda de orientação não é um obscurecimento ou entrave puramente intelectual, mas fundamentalmente afetivo. Aqui nós retornamos ao ponto inicial do nosso texto. Porque, ao colocar o problema do ominoso no campo da questão sobre a orientação, Freud acaba por resgatar um daqueles primeiros filósofos que, em linguagem moderna, apresentaram tais problemas. Em Que significa orientar-se no pensamento, Kant (2008) esclarece que o projeto de uma crítica da razão tem por finalidade determinar os limites das faculdades, o que nos salvaguardaria contra diversos erros, dentre eles o entusiasmo místico, isto é, a suposição de que sejamos capazes de atingir ou conhecer coisas transcendentes. Enquanto Kant aponta para uma ambiguidade intelectual que pode ser desfeita pelo estabelecimento de limites orientadores, Freud revela a dinâmica inconsciente responsável pela angústia constitutiva da ambiguidade no ominoso. Não assumimos neste texto que uma crítica 
dos erros categoriais dissolveria a anedota, nem mesmo assumimos que as explicações psicanalíticas seriam capazes de extirpá-la, o que a reduziria à simples condição de caso. Mesmo que tenha sido como parca indicação, nosso texto mencionou a dificuldade da redução ao fundo teórico psicologista. Concomitantemente, nos seus momentos iniciais, nosso texto lançou mão de um autor que, valendo-se da linguagem e da tradição kantiana, subverte Kant ao sinalizar, por um lado, para conceitos que constituem objetos; por outro lado, para Ideias como elementos incontornáveis do pensamento na determinação daquelas coisas do mundo que não têm o caráter de objetos.

Supondo que a ambiguidade desorientadora e, portanto, ameaçadora, seja um elemento constitutivo do ominoso, as categorias da anormalidade mental, da subcultura e do charlatanismo prestam-se como formas de restaurar a normalidade, de suprimir um ominoso que nos espreita em nossa recôndita familiaridade. Nesse caso, a supressão do ambíguo não é um fenômeno de natureza conceitual, porque não está em jogo o estabelecimento de critérios ou a explicitaçáo dos fundamentos. Por mais que a linguagem jornalística e o discurso das instituições ergam um tom de rigor, suas justificativas sáo conceitualmente precárias. $\mathrm{O}$ feitiço da ambiguidade volta-se contra aqueles que dela se valem como marca acusatória; a fala sobre a falta de rigor é a expressão da falta de rigor. Se antes, para a mídia, as atividades de Seu Sete eram caritativas, agora, nada mais seriam do que disfarces para atividades ilícitas. Assim, em sete de setembro de 1971, o Jornal do Brasil publica matéria indicando que o Ministério da Fazenda submeteria Dona Cacilda de Assis à investigação, a fim de verificar a correção dos seus compromissos para com o imposto de renda (Jornal do Brasil, 07/09/1971, p. 21). O jornal Correio da Manhá, de dois de outubro, em matéria intitulada Fisco dá duro em Seu Sete, as atividades de Dona Cacilda são esmiuçadas, porque diversas empresas teriam sido montadas, ou estariam auferindo lucros, graças ao nome da entidade, que teria virado uma marca comercial (Correio da Manhã, 02/10/1971, p. 6). A explosão do caso sobre Seu Sete teria lançado luz e suspeita sobre outros sacerdotes, fazendo deles possíveis objetos do fisco. Em publicação de vinte de outubro, a revista $O$ Cruzeiro 
(20/10/1971, p. 22-25) traz reportagem em que Cacilda de Assis, lançando mão de uma série de documentos, notas e recibos, tenta demonstrar que seu terreiro não é fonte ilícita de lucros, ao mesmo tempo garantindo que toda receita formada pela venda de produtos em sua instituição religiosa é revertida em obras para a construção da sede definitiva.

Maior prova dos efeitos políticos institucionais da aparição de Seu Sete consta em publicação do Jornal do Brasil, de onze de setembro de 1971. Com o título Programação da Televisão ao vivo faz 3 Ministros se reunirem na segunda-feira, a reportagem revela que o ministro das comunicaçóes, o ministro da justiça e o ministro da educação se encontraram com o intuito de discutir a qualidade da televisão brasileira. A intenção do governo, segundo o ministro das comunicações Higino Corsetti, não seria cassar a concessão dos canais, mas que esses passassem a assumir real responsabilidade pela qualidade das exibiçóes, particularmente aquelas transmitidas ao vivo. A matéria prossegue com as observaçôes de Walter Clark, porta-voz da TV Globo; Almeida Castro, representante da TVTupi; e Paulo de Tarso Montenegro, diretor do IBOPE. O representante da Globo confessa que a gota d'água para a mobilização governamental foi a aparição de Seu Sete. Sobre a sanha pela audiência e a disputa entre emissoras, tanto Walter Clarck quanto Almeida Castro culpam a infraestrutura das emissoras, principalmente artistas e produtores, sendo estes os verdadeiros fomentadores da guerra midiática. A TV Globo decide por diminuir o programa do Chacrinha, reformular seus quadros humorísticos e reduzir drasticamente programas ao vivo. Já a TV Tupi, não escapa à tentativa de justificar o suposto padrão popularesco, particularmente quando Almeida Castro alega: “[...] sobre o problema da programação ao vivo, explicou ele que o temperamento latino exige esse tipo de espetáculo, quando se trata sobretudo de tele reportagens" (Jornal do Brasil, 11/09/1971, p. 13). O diretor do IBOPE oferece uma informação que serviria para balizar a ideia de que o apreço pelo Seu Sete predomina nas classes menos abastadas e instruídas: 
Nesse domingo, os índices apurados pelo Ibope não apresentaram qualquer acréscimo em relação aos domingos anteriores, registrando, na hora da apresentação mediúnica, a percentagem de 42,9 na TV Globo e 34,3, na TV Tupi. Outra estatística do Ibope desconhecida do público é que apenas 30\% das 1105038 unidades familiares com aparelhos de televisão estão localizadas na Zona Sul e Tijuca, relativas às classes A e B. Os restantes 70\% estáo distribuídos nos subúrbios da Central e da Leopoldina e na área do Grande Rio, sendo que $40 \%$ pertencem à classe $\mathrm{C}$ (pobre) e $30 \%$ à classe $\mathrm{D}$ (pobre inferior). (Jornal do Brasil, 11/09/1971, p. 13)

Já dispostas algumas informaçôes sobre o caso do Seu Sete, cabe analisar alguns discursos que conferiram o desenho institucional do conflito engendrado pelo fenômeno. Ressaltamos que tais discursos suprimem o caráter irruptivo da anedota, exatamente porque forçam-na a falar sobre algo que não é ela mesma. A anedota converte-se em circunstância teórica para a tematização de algo que não é sua ocorrência em si: a possibilidade de transmissão de dons espirituais via televisáo; o fato de que pessoas que não confessavam explicitamente uma crença tenham caído em transe; a possibilidade de que uma transmissão provoque o transe em seus espectadores. Há dois eixos discursivos básicos que permitem o emudecimento da anedota. $\mathrm{O}$ eixo que funciona pela categoria da anormalidade; o eixo que funciona pela categoria da imoralidade. Por fim, como forma de análise que permite à anedota falar de si mesma, tratar de sua ocorrência, expressar aquilo que nela é inaudito, extrafamiliar e desorientador, a tal modo de tratamento nós conferimos a expressão paranormal, exatamente por se furtar à dicotomia normalidade e anormalidade. 


\section{ACADÊMICOS E LEIGOS DESORIENTADOS. OU: COMO O FENÔMENO MOSTRA A DEBILIDADE DE SUAS INTERPRETAÇÓES}

Na obra O império do grotesco, Muniz Sodré e Raquel Paiva (2002) abordam o caso de Seu Sete da Lira como circunstância que explicita alguns matizes da dicotomia entre baixa e alta cultura, entre culturalmente sofisticado e popularesco. A estrutura do discurso recorda as críticas ao fenômeno pela Igreja Católica, ao mesmo tempo em que compila algumas críticas e desqualificações ao caso publicados pela imprensa. Curiosamente, os autores sinalizam que o grande alarido contrário a Cacilda de Assis somente ocorre depois de sua apresentaçáo televisiva, mas os autores não registram os momentos de exaltaçáo pela imprensa da figura de Seu Sete. Em conflito com a informaçáo do diretor do Ibope mencionada por nós anteriormente, o livro apresenta uma informaçáo da revista Veja a propósito da grande audiência que Seu Sete teria alcançado em suas apresentaçóes (Paiva; Sodré, 2002, p. 120-128). As campanhas difamatórias envidadas pela imprensa e as medidas repressivas do governo sáo consideradas como expressôes tanto de uma luta de classe, entre as classes subalternizadas e aquela detentora de privilégios econômicos e sociais, quanto uma expressão de racismo constitutivo da sociedade brasileira, o qual continuamente teria impedido as manifestações culturais e religiosas da populaçáo negra, particularmente a partir da suposição de sua inferioridade. Assim sendo, o caso do Seu Sete configura-se como a anormalidade que explodiria com o status quo e, por isso, seria objeto de repressão a fim de que não se propagasse. $\mathrm{O}$ fenômeno seria $\mathrm{o}$ anormal que revela não serem normais os pressupostos estéticos e sociais veiculados pelo status quo e reiterados pela elite.

Ainda que de modo muito breve, Muniz Sodré e Raquel Paiva mencionam uma das fontes conflituosas que estariam emaranhadas nas acusaçóes contra Cacilda de Assis. O interior da umbanda também estaria cindido pela divisão entre alto e baixo espiritismo, alta e baixa magia ou, ainda, entre uma Umbanda autêntica e sua contraparte inautêntica. É neste contexto 
classificatório que os autores mencionam um pretenso mito fundador da Umbanda, o qual se refere ao nascimento dessa religiáo a partir da manifestação da entidade Caboclo Sete Encruzilhadas, por meio de Zélio Fernandino de Moraes, em uma mesa kardecista. Por meio dessa entidade, Zélio supostamente teria conferido os parâmetros da autêntica umbanda. $\mathrm{O}$ discurso dos autores parece corroborar a tese apresentada por Renato Ortiz, em A morte branca do feiticeiro negro (1999), sobre esforços por um expurgo de elementos negros e náo europeus do interior da umbanda, ou mesmo a hierarquização das entidades da umbanda segundo o modelo de estratificação social brasileiro. A ruptura com o modo de análise que acentua o elemento conflituoso e, por conseguinte, a crítica à inferiorizaçáo de um dos grupos em jogo, bem pode ser visto na obra de Yvonne Maggie intitulada Medo de Feitiço: relaçóes de magia e poder no Brasil (1992). Inspirada por Evans-Pritchard, Maggie assume o termo feitiço como um operador lógico responsável por estabelecer hierarquias e classificar grupos. Na condição de categoria de acusação, a denúncia de feitiçaria somente poderia operar e gerar efeito no interior de um grupo que compactue com o sistema de crenças que pressupóe o feitiço. Acusaçôes como charlatanismo ou baixo espiritismo seriam derivaçôes da aceitaçáo do feitiço, exatamente porque os grupos religiosos e não religiosos podem adotá-las em suas acusaçôes contra oponentes. Enquanto no âmbito brasileiro a feitiçaria como sistema de crença seria um fato social, a partir do qual os poderes legislativo e jurídico operariam, a autora nos remete ao Zimbábue, onde a acusação de feitiçaria é legalmente proibida. Esse dispositivo legal impediria que as categorias de acusação derivadas do feitiço se engendrassem no sistema legal e nas instituiçōes amparadas no Estado.

Em Medo de Feitiço (1992), Yvonne Maggie dedica a seção 26 do sexto capítulo ao caso de Seu Sete. Após oferecer breve descrição historiográfica de Cacilda de Assis, sua entidade e as práticas no terreio, a autora apresenta as críticas da Igreja Católica, cuja natureza foi já mencionada por nós. Recorda que Cacilda de Assis já fora objeto de críticas por parte de alguns babalorixas e yalorixas antes da retumbante apresentação na televisão. Contudo, o 
campo de análise de nosso maior interesse - e de amplo destaque conferido pela autora - está situado na Assembleia Legislativa do Estado da Guanabara. Dois deputados entram em conflito sobre as figuras de Seu Sete e de Cacilda de Assis. De um lado, Átila Nunes Filho ataca os personagens do terreiro de Santíssimo; do outro lado, Rossine Lopes da Ponte, assíduo das giras de Seu Sete, sai em defesa da entidade e de sua médium. Antes mesmo que todo o quiproquó televisivo se instaurasse, Átila Nunes Filho havia enviado ofícios à Secretaria de Fiscalizaçáo solicitando maior repressáo em relação àqueles espíritas que supostamente abusariam da fé dos crédulos. Sua atuação também foi relevante para que o fisco voltasse sua atenção para o terreiro de Cacilda de Assis. Rossine Lopes tenta angariar apoio daquelas federaçóes religiosas sobre as quais exerce alguma influência. Aparentemente, Rossine sai perdedor dessa disputa, porque é sob a égide de Átila Nunes Filho, quinzes dias após a aparição de Seu Sete, que é fundado o Conselho Nacional Deliberativo de Umbanda. Rossine e Átila são aliados na crítica aos ataques da Igreja contra a umbanda, mas são rivais quanto às práticas do terreiro de Santíssimo. Yvone Maggie, em suas análises, destaca a luta de poder entre os deputados, cabendo a Átila Nunes o papel daquele que almeja o poder de institucionalizar os critérios sobre o que seria o bom e o mau espiritismo. E esse é o ponto crucial, uma vez que não há critério algum. A vacuidade de parâmetros expressa-se no pedido de Átila Nunes a fim de que o fisco lance suas redes sobre Seu Sete, mas que não faça o mesmo em relação aos demais terreiros, visto que eles desfrutam legalmente da isenção de impostos. Concomitantemente, antes que o Ministério das Comunicaçôes começasse a se mover em relação à censura dos programas ao vivo, Átila Nunes reivindicava a maior atuação dos órgãos censores, destacando que ao seu grupo doutrinário e partidário, supostamente legítimos representantes da umbanda, caberia oferecer os critérios da censura. Seu Sete da Lira é um caso de exceção que confirma um perpétuo estado de exceção.

O caso do Exu Seu Sete da Lira é posto por Yvonne Maggie como exemplar porque, supostamente, confirma a sua tese. $\mathrm{O}$ feitiço seria um operador lógico capaz de classificar grupos e hierarquizar. Ambos procedimentos estáo 
ancorados em um sistema de crenças sobre o feitiço, em alguma medida compartilhado por acusados e acusadores. Não existiria uma instância capaz de acusar ou ser acusada sem que compactuasse com o sistema, o que enfraqueceria a tese de uma instância exterior que dominaria e exerceria seu poder sobre uma instância mais fraca, sendo a parte dominadora supostamente responsável pelos mecanismos ideológicos que controlaria os mais débeis. O núcleo da tese da autora é extraído de Foucault, particularmente de sua História da Sexualidade (1988). A imagem oferecida pela autora sobre o feitiço é de um factum social em ação; e a expressão operador lógico para qualificá-lo, ainda que esvaziado de seu caráter puramente cognitivo, afigurase como instância que ordena o processo e justifica seu caráter estabelecedor da verdade. Contudo, Foucault também poderia ser usado contra Yvonne Maggie, bem como a favor de um resgate do fenômeno. Se, por um lado, a autora destaca que a dicotomia entre acusados e acusadores náo pode ser reduzida ao par oprimidos e opressores; por outro lado, o operador lógico escamoteia as contradiçóes e as tensôes de sua falta de lógica. A vontade de verdade ainda tem que responder sobre os seus critérios e sobre sua coerência. Se isso não ocorre, ainda mais em circunstâncias carregadas de interfaces com o Estado, então estamos diante de um grave fenômeno já tematizado por Foucault: a linguagem Ubu.

No período de 1974-1975, em seu curso ministrado no Collège de France, Michel Foucault debruça-se sobre a categoria da anormalidade. Suas investigaçóes iniciam-se a partir do Código Penal francês de 1810, levando em conta, particularmente, o artigo 64, para o qual não há delito ou crime caso o indivíduo se encontre em estado de demência no momento do crime. Será principalmente na aula de quinze de janeiro de 1975 que Foucault descreverá a condição epistemologicamente precária da ponte entre sistema jurídico e sistema psiquiátrico, inconsistência esta concretizada na figura do perito. Seus argumentos são bastante precisos ao reiterar que não está colocando em jogo a consistência teórica do campo psiquiátrico, com os seus impasses e conflitos conceituais. Antes, aponta para a regiáo da perícia como incapaz de cumprir sua pretensão: demonstrar o nexo causal 
entre doença mental e a ação criminosa. A linguagem que predominaria na perícia, no nexo entre os campos psiquiátrico e jurídico, seria o biográfico, com forte carga moralista. As categorias de base dessa linguagem seriam a perversão e o medo:

Quando vocês percorrem esses exames médico-legais, como os que li da última vez, o que mais salta aos olhos são termos como "preguiça”, "orgulho", "obstinação", "maldade"; o que nos é relatado são os elementos biográficos, mas que náo são de maneira nenhuma princípios de explicação do ato, e sim espécies de reduções anunciadoras, de pequenas cenas infantis, de pequenas cenas pueris, que já são como que o análogo do crime. Uma espécie de redução para crianças da criminalidade, qualificada por termos iguais aos utilizados pelos pais ou na moral dos livros infantis. Na verdade, essa puerilidade mesma dos termos, das noçóes e da análise, que está no âmago do exame médico-legal contemporâneo, tem uma função muito precisa: é ela que vai servir de ponte entre as categorias jurídicas, que são definidas pelo próprio Código e que pretendem que só se pode punir se houver verdadeiramente intenção de causar dano ou dolo, e noçôes médicas, como as de "imaturidade", de "debilidade do Eu", de "não-desenvolvimento do superego", de "estrutura de caráter", etc. Como vocês estão vendo, noçóes como todas as que, grosso modo, estão ligadas à perversidade permitem costurar, uma na outra, a série das categorias jurídicas que definem o dolo, a intenção de causar dano, e as categorias mais ou menos constituídas no interior de um discurso médico ou, em todo caso, psiquiátrico, psicopatológico, psicológico. Todo esse campo das noçóes da perversidade, postas em circulação em seu vocabulário pueril, permite pôr as noçôes médicas para funcionar no campo do poder judiciário e, inversamente, as noções jurídicas no campo de competência da medicina. É como ponte, portanto, que ele funciona bem, e funciona tanto melhor quanta mais fraco for epistemologicamente (Foucault, 2001, p. 41-42).

A debilidade epistêmica preenchida pela infantilidade moralista significaria um aviltamento e rebaixamentos das esferas psiquiátrica e jurídica; o discurso da perversáo e do medo, diante da falta de acuidade intelectual, são as formas de rebaixamento epistemológico que permitem o exercício 
do poder. Foucault traça um paralelo entre tal estado e a figura do Ubu-Rei, personagem de Alfred Jarry: a condição grotesca e ridícula do tirano Ubu infunde o medo necessário para sustentar o seu poderio. Para que nos detenhamos exclusivamente no caso de Seu Sete da Lira, os discurso de tutela cultural, de zelo pela saúde psíquica da sociedade e de proteção jurídica dos inocentes contra o charlatanismo, todos eles compartilhados pela Igreja Católica, pelo Estado e pelas grandes corporaçóes da iniciativa privada - no caso, as mídias em jogo - expressam a mesma carência de critérios, a mesma dependência das exceçóes ad hoc, que os discursos do deputado Átila Nunes Filho contra o Exu Sete da Lira: suas categorias de acusação poderiam se voltar contra ele mesmo, mas somente não se voltam porque são aplicadas a uma exceção. Seu poder confirma-se, porque ele enuncia quem é a exceção.

Por certo não se trata, assim como em Foucault, de valer-se da marca Ubu como uma desqualificação de indivíduos ou discursos. Trata-se de apresentar uma estrutura recorrentes em instâncias que, assumidas como autoridades especialistas, fazem a mediação entre Estado e sociedade. Sua precariedade epistêmica e seu rebaixamento são as condiçóes de possibilidade para o exercício do poder. Aquele que se arroga como especialista em umbanda, em defesa da umbanda, coloca em xeque o umbandismo. A instância religiosa, que defende a liberdade de culto, arroga para si o poder de decidir o que é autenticamente expressão de religiosidade, com categorias moralistas que também poderiam se voltar contra ela. A instância psiquiátrica apenas oferece pareceres morais, alertas de perigos sociais e suspeitas na biografia dos envolvidos, sem se voltar para a tematização do fenômeno em jogo. Poderíamos suspeitar de que o acionamento da categoria de acusação feitiço traria em si a possibilidade de que seus desdobramentos categoriais hierarquizantes, tais como bom e mau, pudessem se voltar contra eles mesmos. Mas o caso de reversão entre instituiçôes consolidadas e grupos minoritários dificilmente aparece. A persistência do seu uso transparece um caráter assimétrico, o que indica a possibilidade de compreender o feitiço não como um operador lógico, mas como uma categoria de imunização: corre-se o risco de assumir no corpo o patógeno com o fim de criar defesas 
contra a doença, o que resultaria em maior eficácia para a eliminação do anormal. Assim como Yvonne Maggie, em Guerra de Orixás (2001), confessa o medo de ser possuída por uma entidade, as instituiçóes brasileiras podem nutrir aversão ao risco de que um fenômeno exótico venha a possuir seu corpo e desestabilizar seus pilares.

\section{O DOM DA PRESENÇA: A CAPACIDADE DE SE REORIENTAR AO DEIXAR O FENÔMENO FALAR}

Há quem tenha assumido tais riscos, em circunstâncias similares àquelas apresentadas pelo caso do Seu Sete? Há circunstâncias em que o feitiço, em lugar de ser operador lógico para o estabelecimento de grupos e hierarquias, tenha se convertido em instrumento de reflexão e tematização de categorias básicas em que as instituições estão assentadas, e isso pelos próprios agentes das instituiçõoes? Stefan Andriopoulos explora as relações e codeterminação entre discursos médicos, jurídicos, artísticos a propósito do fenômeno da hipnose e da possibilidade de indução do hipnotizado ao crime. Na obra Possuidos: crimes hipnóticos, ficção corporativa e a invenção do cinema (2014), o autor inicia sua investigação a partir dos conflitos entre escolas psicológicas sobre os fatores que determinariam a condição influenciável de um hipnotizado. A análise não se volta simplesmente para a disputa teórica, mas explicita como o discurso literário mantém uma relação de retroalimentação com o discurso jurídico e psiquiátrico. $\mathrm{O}$ pareamento entre literatura e ordem jurídica poderia ser vista como uma simples coincidência temática, não fosse o fato de que o campo jurídico ao qual o autor lança sua atenção, o direito alemão da segunda metade do XIX, estivesse discutindo o próprio estatuto da ficção, da possibilidade de uma pessoa fictícia, notadamente para o caso da pessoa jurídica. Não se trata de filigranas conceituais, mas sim de estabelecer se pessoas jurídicas podem ser imputadas na esfera criminal. Literatura, psiquiatria e direito entrecruzam-se até mesmo na explicitação da natureza da pessoa corporativa, lançando como possibilidade verossímil 
que a corporação possa ter controle sobre os seus membros através de indução hipnótica. Se as empresas perfazem a unidade de um corpo graças à mediação da hipnose, sub-repticiamente inoculada nos membros que as compõem, então, é possível uma ação hipnótica mediada pela própria mídia, como seria o caso da suspeita que recairia sobre o cinema ou o rádio.

O estatuto da pessoa de Seu Sete, manifestado por Cacilda de Assis, somente alcança algum nível de tematização pela imprensa através das categorias patológicas, sendo o mesmo para aquelas personalidades despertadas nos espectadores quando tomados pelo transe. A mídia e os conglomerados midiáticos jamais são tematizados como produtores de alteração das consciências ou como sustentando sua unidade empresarial por meio hipnótico. A igreja recusa-se a tecer qualquer paralelo entre os seus sacramentos como mídia para dons espirituais e a mídia como veículo espiritual do Exu Sete da Lira. Ao fim e ao cabo, a tese de Yvonne Maggie supondo o caso de Cacilda de Assis como paradigmático, longe de confirmar, parece destruir o princípio metodológico do operador lógico defendido pela autora. As categorias de acusação disparadas pelo operador feitiço não ratificam um sistema de crenças, mas abrem margem para a desaparição, despresentificação do fenômeno, seja pela via judicial, através da figura do perito, seja através da imprensa, da psiquiatria ou da Igreja Católica. Se Evans-Prichtard é utilizado por Maggie como fundamento metodológico para a análise do caso de Seu Sete, nós podemos considerar que sua tese é o anti-Evans-Prichtard ou, pelo menos, o contrário do que expressa a mais famosa anedota contida em Bruxaria, Oráculo e Magia entre os Azande (2005): a famigerada anedota conhecida como o caso da luz da bruxaria. Narra Evans-Pritchard:

Apenas uma vez pude ver a bruxaria em seu caminho. Ficara escrevendo até tarde, em minha cabana. Por volta de meia-noite, antes de me recolher, tomei de uma lança e saí para minha costumeira caminhada noturna. Andava pelo jardim atrás de minha cabana, entre bananeiras, quando avistei uma luz brilhante passando pelos fundos do abrigo de meus criados, em direção à residência de um homem chamado Tupoi. Como aquilo parecia merecer uma investigação, 
comecei a segui-la até que um trecho de relva alta obscureceu minha visão. Corri depressa, atravessei minha cabana e saí do outro lado, de forma a ver aonde a luz estava indo; mas não consegui mais enxergá-la. Sabia que apenas um dos meus criados tinha uma lamparina capaz de emitir luz táo brilhante. Mas na manhã seguinte ele me disse que não tinha saído àquela hora e nem usara a lamparina. Não faltaram informantes solícitos para dizer que o que eu tinha visto era bruxaria. Pouco depois, na mesma manhã, morria um velho parente de Tupoi, agregado à sua residência. (Evans-Pritchard, 2005, p. 42-43).

Ainda que Evans-Pritchard sinalize para a possibilidade de uma coincidência, - até mesmo erguendo a hipótese de que alguém tenha acendido um facho para defecar durante a noite -, a intensidade da luz e a morte no local previsto servem como testemunho da presença do ominoso e de convocaçáo para o deslocamento de orientação. Os princípios causais da mentalidade científica moderna apresentam-se como insuficientes, enquanto a malha de orientaçáo dado pelo sistema dos Azande compreendem e justificam o fenômeno. No caso de Seu Sete, a forma dos discursos desqualifica ou desloca o fenômeno rumo a instâncias subterrâneas e externas: o estranho ao fenômeno funda o fenômeno, como se ele fosse a imagem superficial de causas reais. No caso da luz da bruxaria, o fenômeno é testemunha de si mesmo, testifica o discurso dos Azande sobre o feitiço, lançando a sombra da dúvida sobre as outras formas de orientação causal que pretendam dar conta do evento.

Talvez a postura mais adequada diante do fenômeno do ominoso seja exemplificada por um pesquisador das tradiçóes de matriz africana, particularmente do sistema oracular de Fá. Provavelmente, nós devêssemos abandonar o medo em favor do espanto: assumir a postura de Bernard de Maupoil (2017), na obra A Advinhação na Antiga Costa dos Escravos, que lamenta a ordem normal de suas atividades administrativas e burocráticas, responsáveis por surrupiar o precioso tempo necessário para se debruçar sobre o paranormal, sobre o extraordinário, sobre o não familiar:

Este exame do papel e das capacidades dos adivinhos seria incompleto caso não fizesse mençẫo às faculdades paranormais de alguns deles. Pudemos notar 
na presença de Gédégbe que ele, com frequência, tomava conhecimento de situaçôes inatingíveis apenas pelo exercício normal do raciocínio e sem que um estado mórbido justificasse esse alargamento especial da sensibilidade. Foi assim que ele nos revelou que um acidente automobilístico fatal ameaçava o nosso amigo Fernand Audric, uma semana antes que o infeliz, perdido subitamente no deserto da Núbia, morresse de insolação e de sede com outros três companheiros de viagem. Gédégbe não sabia que o nosso amigo havia escolhido o caminho terrestre para voltar da França, após as férias, e nos pressionou para passarmos-lhe um telegrama recomendando-lhe que, durante as escalas, não saísse do navio que ele deveria tomar normalmente. Informaçóes desse gênero, por parte de Gédégbe, sempre se referiam a situaçóes da vida ou a fatos que estavam para ocorrer, imprevisíveis, sim, mas parcialmente atualizados. Poder-se-ia dizer que Fá exerce no mundo uma função geral de metagnomia. Ele não apenas percebe e revela em cada um de nós o acontecimento como ainda se dirige ao fazun, ao ser mais profundo. Quando o adivinho é competente, as coisas ocorrem como se ele transpusesse, por um instante, uma modalidade desconhecida do pensamento para o plano consciente.

A atenção que tínhamos de dedicar a uma tarefa administrativa exigente e a complexidade dos fenômenos considerados nos impediram de proceder a uma investigação metódica desses pré-conhecimentos, cuja "operação intrapsíquica" nem sempre nos oferece uma explicação suficiente (Maulpoil, 2017, p. 137-138, grifos do autor).

\section{REFERENNCIAS}

AMARAL, Zózimo Barroso do. Jornal do Brasil, Rio de Janeiro. Caderno B, p. 3, 2-3 mai. 1971.

ANDRIOPOULOS, Stefan. Possuidos: crimes hipnóticos, ficção corporativa e a invenção do cinema. Tradução de Vera Ribeiro. Rio de Janeiro: Contraponto, 2014. 
BASTIDE, Roger. O Candomblé da Bahia: rito nagô. Tradução de Maria Isaura Pereira de Queiroz. São Paulo: Companhia Editora Nacional, 1961. BASTIDE, Roger. Diálogo entre Filhos de Xangô: Correspondência 19471974. Apresentação e notas de Françoise Morin. Tradução de Regina Salgado Campos. São Paulo: Editora da Universidade de São Paulo, 2017.

BERNARD, Maupoil. A adivinhação na Antiga Costa dos Escravos. Tradução e Organização de Carlos Eugênio Marcondes de Moura. São Paulo: Editora Universidade de São Paulo, 2017.

BLUMENBERG, Hans. Teoria da não conceitualidade. Tradução e introdução de Luiz Costa Lima. Belo Horizonte: UFMG, 2013.

BLUMENBERG, Hans. The laughter of the Thracian woman: a protohistory of theory. Tradução de Spancer Hawkins. Nova York: Bloomsbury Academics, 2015.

BLUMENBERG, Hans. Paradigms for a Metaphorology. Tradução de Robert Savage. Nova York: Cornell University Press, 2010.

CABRERA, Lydia. A Mata: notas sobre as religióes, a magia, as superstições e o folclore dos negors criollos e o povo cubano. Tradução de Carlos Eugênio Marcondes de Moura. São Paulo: Edusp, 2012.

CAPONE, Stefania. A busca da África no Candomblé. Tradição e Poder no Brasil. Tradução de Procópio Abreu. Rio de Janeiro: Editora Pallas, 2004.

CASTILLO, Lisa Earl. A fotografia e seus usos no candomblé da Bahia. Pontos de interrogação, Alagoinhas, v. 3, n. 2, jul./dez., 2013.

DUMÉZIL, Georges. Idées Romaines. Paris: Gallimard, 1969.

ELIADE, Mircea. O Sagrado e o Profano. Tradução de Rogério Fernandes. São Paulo: Martins Fontes, 1992.

EVANS-PRITCHARD, E. Bruxaria, Oráculo e Magia entre os Azande. Edição resumida e introdução de Eva Gillies. Tradução de Eduardo Viveiros de Castro. Rio de Janeiro: Zahar, 2005. 
FOUCAULT, Michel. Os anormais: Curso no Collège de France (19741975). Tradução de Eduardo Brandão. Sáo Paulo: Martins Fontes, 2001.

FOUCAULT, Michel. História da sexualidade I: a vontade de saber. Tradução de Maria da Costa Thereza Albuquerque e J. A. Guilhon Albuquerque. Rio de Janeiro: Ediçōes Graal, 1988.

FREUD, Sigmund. Lo ominoso. In: FREUD, Sigmund. Obras Completas. vol. 17. Tradução de José L. Etcheverry. Buenos Aires: Amorrortu editores, 1992. GUMBRECHT, Hans Ulrich. Produção de presença - o que o sentido não consegue transmitir. Tradução de Ana Isabel Soares. Rio de Janeiro: Contraponto: PUC-Rio, 2010.

JAEGGER, Werner. On the Origin and Cycle of the Philosophic Ideal of Life. In: JAEGGER, Werner. Aristotle: fundamentals of the history of his development. Traduçâo de Richard Robinson. Oxford: Clarendon Press, 1968. KANT, Immanuel. Que significa orientar-se no pensamento. In: KANT, Immanuel. A paz perpétua e outros opúsculos. Tradução de Artur Morão. Lisboa: Edições 70, 2008.

KANT, Immanuel. Crítica da Razão Pura. In: KANT, Immanuel. Coleção os pensadores. Tradução de Valério Rohden e Udo Baldur Moosburger. São Paulo: Editora Nova Cultural, 2000.

KANT, Immanuel. Crítica da Faculdade do Juizo. Tradução de Valério e Antonio Marques. 2 ed, Rio de Janeiro: Forense Universitária, 1995.

LEMOS, Ubiratan; QUEIROZ, Vieira de; VIEIRA, José Carlos de. O Maracanã da Fé. Revista O Cruzeiro, Rio de Janeiro, n. 26, p. 38-45, jun. 1971. LOPES, Wanderley; QUEIROZ, Vieira; WANDERLEY, Idalécio. Salve Seo Sete: a nova dimensão da umbanda. Revista O Cruzeiro. Rio de Janeiro, n. 20, p. 4-14, mai. 1971.

MAGGIE, Yvonne. Guerra de Orixás: um estudo de ritual e conflito. Rio de Janeiro: Jorge Zahar, 2001. 
MAGGIE, Yvonne. Medo de Feitiço: relaçóes de magia e poder no Brasil. Rio de Janeiro: Imprensa Nacional, 1992.

MONTEIRO, Denilson; NASSIFE, Eduardo. Chegou Seu Sete da Lira. In: MONTEIRO, Denilson; NASSIFE, Eduardo.Chacrinha, a biografia. Rio de Janeiro: Casa da Palavra Produçáo Editorial, 2014.

PLATÃO. Mênon. Texto estabelecido e anotado por John Burnet. Traduçáo de Maura Iglésias. Rio de Janeiro: PUC-RIO, 2001.

PELIKAN, Jaroslav. A tradição cristã: uma história do desenvolvimento da doutrina. v. 3. Traduçáo de Lena Aranha e Regina Aranha. São Paulo: Shedd, 2015.

PERELMAN, Chäim; OLBRECHTS-TYTECA, Lucie. Tratado da argumentação: a nova retórica. Tradução de Maria Ermantina de Almeida Prado Galvão. São Paulo: Martins Fontes, 2005.

PORT, Mattijs van der. Visualizing the sacred: video technology, televisual style, and the religious imagination in Bahia candomblé. In: PORT, Mattijs van der. American Ethnologist, California, v. 33, n. 3, 2006.

ORTIZ, Renato. A morte branca do feiticeiro negro: umbanda e sociedade brasileira. São Paulo: Brasiliense, 1999.

RAMOS, Arthur. O Negro Brasileiro. São Paulo: Companhia Editora Nacional, 1940.

RICOEUR, Paul. A Metáfora Viva. Tradução de Dion Davi Macedo. São Paulo: Loyola, 2000.

SILVA, Arlindo; MEDEIROS, José. Noivas dos deuses sanguinários. Revista O Cruzeiro, Rio de Janeiro, ano 23, n. 48, p. 12-128, mai. 1951.

SODRÉ, Muniz; PAIVA, Raquel. O império do Grotesco. Rio de Janeiro: MAUAD, 2002.

TACCA, Fernando. Imagens do Sagrado: entre Paris Match e O Cruzeiro. Campinas: UNICAMP, 2009. 
TVS AFIRMAM protocolo contra show de baixo nível. Jornal do Brasil, Rio de Janeiro, Primeiro Caderno. 03 set. 1971, p. 12.

SECRETÁRIO de finanças diz que não pretende fazer nada contra o Seu Sete. Jornal do Brasil, Rio de Janeiro, Primeiro Caderno. 06 set. 1971. p. 42.

FAZENDA vai baixar em diligência no terreiro. Jornal do Brasil, Rio de Janeiro, Primeiro Caderno. 07 set. 1971, p. 21

UMBANDA acusa Seu Sete de deturpar a religiăo. Correio da manhä, Rio de Janeiro, Primeiro Caderno. 14 set. 1971. p. 5

CANDOMBLÉ luta contra mistificaçáo. Correio da manhã, Rio de Janeiro, Primeiro Caderno. 27 set. 1971. p. 5.

FISCO dá duro em Seu Sete. Correio da manhä, Primeiro Caderno, Rio de Janeiro, 2 out. 1971. p. 6.

SEU Sete falou e disse, com documentos na mão: tudo legal com Seu 7 , que, através de Mãe Cacilda, seu cavalo, também paga Imposto de Renda. Revista O Cruzeiro, Rio de Janeiro, n. 42, 20 out. 1971.

PROGRAMAÇÃO da Televisão ao vivo faz 3 Ministros se reunirem na segunda-feira. Jornal do Brasil, Primeiro Caderno, Rio de Janeiro, 11 set. 1971. p. 13.

Recebido em: 01/10/2018 Aprovado em: 01/02/2019 


\section{ENSAIO FOTOGRÁFICO}

